\title{
Comparing Levels of Anxiety During Bed and Shower Baths in Patients with Acute Myocardial Infarction
}

\author{
Juliana de Lima Lopes ${ }^{1}$ \\ Luiz Antonio Nogueira-Martins ${ }^{2}$ \\ Maria Aparecida Batistão Gonçalves ${ }^{3}$ \\ Alba Lucia Bottura Leite de Barros ${ }^{4}$
}

\begin{abstract}
This study compared the levels of anxiety presented by patients with acute myocardial infarction in bed and shower baths and the influence of antecedent variables: age, gender, medications, previous hospitalization and/or bed bath, patients' preference regarding the professional's gender, risk factors and anxiety-traits. This crossover study was conducted between February and August 2007 in coronary units. The sample was composed of 71 patients with acute myocardial infarction. The State-Trait Anxiety Inventory (STAI) was applied before the baths (bed and shower baths), immediately after the baths and twenty minutes after the second evaluation. Results revealed that patients were more anxious in the bed bath than in the shower in the three assessments $(p<0.0001)$ and the only variable that interfered with state-anxiety was high blood pressure.
\end{abstract}

Descriptors: Anxiety; Baths; Myocardial Infarction.

\footnotetext{
${ }^{1}$ RN, Ph.D. in Sciences, Instituto do Coração, SP, Brazil. E-mail: julianalimalopes@gmail.com.

${ }^{2}$ Free Lecture, Associate Professor, Universidade Federal de São Paulo, SP, Brazil. E-mail: nogmart2004@yahoo.com.br.

${ }^{3}$ RN, M.Sc., Instituto do Coração, Brazil. E-mail: enfmariap@incor.usp.br.

${ }^{4}$ RN, Full Professor, Universidade Federal de São Paulo, SP, Brazil. E-mail: barrosalba@denf.epm.br.
}

Corresponding Author:

Juliana de Lima Lopes

Universidade Federal de São Paulo. Escola Paulista de Enfermagem

Rua Napoleão de Barros, 754

Vila Clementino

CEP: 04024-002 São Paulo, SP

E-mail: juliana.lopes@incor.usp.br 


\title{
Comparação do nível de ansiedade entre o banho de chuveiro e o de leito em pacientes com infarto agudo do miocárdio
}

Este estudo teve como objetivo comparar os níveis de ansiedade, gerados no banho no leito e no de chuveiro, em pacientes com infarto agudo do miocárdio, bem como a influência de variáveis antecedentes: idade, sexo, medicações, internação e/ou banho no leito prévio, preferência do paciente quanto ao sexo do profissional, fatores de risco e ansiedade-traço. Esta pesquisa é um estudo cross-over, realizado entre fevereiro e agosto de 2007, em Unidades Coronárias. A amostra foi constituída por 71 pacientes com infarto agudo do miocárdio. O instrumento utilizado foi o IDATE-estado, sendo aplicado antes dos banhos (leito e chuveiro), imediatamente após os banhos e vinte minutos após a segunda avaliação. Os resultados mostraram que os pacientes ficaram mais ansiosos quando realizaram seu banho no leito do que quando realizaram o banho de chuveiro, nas três avaliações $(p<0,0001)$ e a única variável que interferiu na ansiedade-estado foi a hipertensão arterial.

Descritores: Ansiedade; Banhos; Infarto do Miocárdio.

\section{Comparación del nivel de ansiedad entre el baño de ducha y el realizado en la cama en pacientes con infarto agudo del miocardio}

\begin{abstract}
Este estudio tuvo como objetivo comparar los niveles de ansiedad, generados en el baño en la cama y en el baño de ducha, en pacientes con infarto agudo del miocardio, así como la influencia de las variables antecedentes: edad, sexo, medicaciones, internación y/o baño en la cama previo, preferencia del paciente en cuanto al sexo del profesional, factores de riesgo y la ansiedad de trazo. Esta investigación es un estudio cross-over, realizado entre febrero y agosto de 2007, en Unidades Coronarias. La muestra fue constituida por 71 pacientes con infarto agudo del miocardio. El instrumento utilizado fue el IDATE-estado, siendo aplicado antes de los baños (cama y ducha), inmediatamente después de los baños y veinte minutos después de la segunda evaluación. Los resultados mostraron que los pacientes quedaron más ansiosos cuando realizaron su baño en la cama que cuando realizaron el baño de ducha, en las tres evaluaciones $(p<0,0001)$ y la única variable que interfirió en la ansiedad estado fue la hipertensión arterial.
\end{abstract}

Descriptores: Ansiedad; Baños; Infarto del Miocárdio.

\section{Introduction}

Anxiety is one of the most immediate and intense psychological responses to acute myocardial infarction (AMI). Coronary patients might present 26\% more anxiety than patients with psychiatric disorders ${ }^{(1)}$.

The association of anxiety and AMI negatively affects the prognosis of these patients ${ }^{(1-3)}$. A high level of anxiety in the first 48 hours after hospitalization increases the chances of developing complications by 4.9 times during hospitalization in comparison to patients with a low level of anxiety ${ }^{(1)}$. Anxiety activates the sympathetic nervous system increasing cardiac contractility, blood pressure, cardiac frequency and consumption of oxygen, worsening the development of the disease ${ }^{(4-5)}$.

Rules established in hospital settings force individuals to constantly adapt, which in addition to patients' need to cope with pain and the threat of death, also causes anxiety ${ }^{(6-7)}$. We frequently observe in clinical practice that anxiety becomes more intense depending on the procedure that the patient is undergoing, such as receiving a bed bath.

The exacerbation of this feeling is understandable given the sociocultural context in which we live, where 
it is not "appropriate" to undress in front of others. Additionally, because this is a routine procedure, professionals frequently forget they are managing the body of another, invading individuals' privacy and intimacy, which can trigger adverse reactions such as anxiety and dissatisfaction ${ }^{(8-9)}$.

There are several studies in the literature evaluating the perceptions of patients in view of bed baths, which they consider unpleasant ${ }^{(8,10-11)}$, embarrassing(10,1213), difficult(10,14), uncomfortable(10), dry ${ }^{(10)}$, $\operatorname{cold}^{(10)}$, incomplete ${ }^{(10)}$, inhuman ${ }^{(10)}$, long ${ }^{(10)}$, and unsatisfactory ${ }^{(10)}$. However, there are no studies quantifying and comparing the anxiety generated during bed and shower baths nor the potential variables that can modify this anxiety.

For this reason, this study's objectives were:

- to compare levels of anxiety generated during AMI patients' bed and shower baths hospitalized in Coronary Care Units (CCU);

- to evaluate the influence of several variables on patients' anxiety in view of bed and shower baths.

\section{Method}

This crossover study was carried out in the CCU of the Heart Institute at the Hospital das Clinicas of the University of Sao Paulo Medical School (HCFMUSP) between February and August 2007.

This study is a special type of clinical trial in which patients received two types of treatment, in a specific or random order. The advantage of this study is that the patients themselves serve as the control group; consequently, fewer individuals are needed compared to conventional clinical trials ${ }^{(17)}$.

The population sample was composed of 71 patients with AMI (with or without ST-segment elevation), hospitalized in the CCU, including patients of both genders, who signed consent forms.

The following inclusion criteria were used: patients with Killip I and II, literate, with no visual impairment, younger than 80 years old and who agreed to participate in the study. The exclusion criteria were: the presence of arrhythmias (ventricular tachycardia, second or third degree atrioventricular block); ischemic pain; patients with Killip III and IV; invasive procedures at the moment of data collection, such as catheterization, surgery and situations in which patients were not capable of filling out the questionnaires (altered levels of consciousness, visual impairment and/or patients who could not read and/or write).

Data collection was carried out at two different points:
- first point: the second bed bath after hospitalization;

- second point: the second shower bath, only after the medical team authorized this procedure.

The patients remained reclined during the bed bath and were assisted by a nursing professional. For the shower bath, a shower chair was used and patients took their bath without direct assistance, though they were under supervision.

It is important to mention that nursing professionals did not receive any type of additional training concerning the baths. These procedures were carried out according to the unit's normal routine and by professionals who were responsible for the patients at the point of data collection. However, aiming to diminish the influence of interpersonal conversation during the procedures, the professionals were instructed to keep to a neutral and superficial conversation.

The instrument used to evaluate anxiety was the State-Trait Anxiety Inventory (STAI). This self-applied inventory is the most complete and commonly used instrument in studies evaluating levels of anxiety and was translated and validated in Brazil. It has two distinct scales with scores that range from 20 to 80 points; the higher the score, the higher the patients' anxiety. In addition to the use of scores to evaluate the results, we opted to categorize anxiety ${ }^{(18-19)}$ : low anxiety (20-34 points), moderate anxiety (35-49 points), high anxiety (50-64 points) and very high anxiety (65-80). This categorization was considered valid both for the state and trait-anxiety.

The state-STAI evaluates anxiety at the point of the questionnaire's application and was applied at the two previously described points (second bed bath and second shower bath) and three evaluations were carried out for each of these applications: a) before the procedure (aiming to evaluate the patient's expectations); b) immediately after the bath (to evaluate the anxiety presented by the patient at the time of these procedures) and c) 20 minutes after the second evaluation (to evaluate anxiety over time).

Jointly with the state-STAI, vital signs (heart frequency, hypertension and respiratory frequency) were assessed, since anxiety can alter these parameters.

The trait-anxiety evaluates the anxiety profile of patients and was evaluated only once, immediately after the third evaluation of state-anxiety and was considered one of the antecedent variables.

The antecedent variables are variables that occur before the study, are preexistent and can affect the dependent variable(s) ${ }^{(20)}$. The variables selected for 
this study were: age, gender, patients' preference for a female or male professional to give the bath, previous hospitalization and/or baths, risk factors for cardiac diseases, trait-anxiety and use of anxiolytics. These variables were correlated with state-anxiety generated during the bed and shower baths.

The following statistical methods were used to analyze the results: the method of repeated measures ANOVA, was used to verify the correlation of stateanxiety generated during the bed and shower baths and also the correlation of antecedent variables with stateanxiety; Person's correlation analyzed the correlation of state-anxiety with trait-anxiety; and Generalized Estimating Equations were used to verify the correlation between state-anxiety and vital signs. The adopted level of significance was $5 \%$.

The research project was evaluated and approved by the Ethics Committee at the hospital where the study was carried out. The study's participants were asked whether they agreed to participate in the study and authorized the use of collected data, and signed free and informed consent forms.

\section{Results}

The sample was composed of 71 patients; 31 $(43.7 \%)$ of them were female. The average age was 58.8 years, while patients between 53 and 61 years predominated.

In relation to risk factors related to cardiovascular diseases, the most frequently found were: sendentariness (74.6\%), hypertension (73.2\%) and family history of cardiovascular disease (71.8\%).

The majority of patients included in the study used betablockers (77.6\%), anti-hypertensive medication $(84.5 \%)$, vasodilators $(57.7 \%)$, anxiolytic benzodiazepines $(39.4 \%)$ or non-benzodiazepine anxiolytics $(2.9 \%)$ during the period of data collection.

Regarding their previous experiences with hospitalization and bed baths, we verified that 53 (74\%) patients were previously hospitalized and $68 \%$ had experienced previous infarctions. Regarding previous bed baths, 31 (43.66\%) reported having experienced it at least once.

In relation to the gender of professionals who would perform the baths, seven patients $(9.86 \%)$ preferred a male professional, $28(39.44 \%)$ preferred a female professional and $36(50.70 \%)$ did not mind whether the professional was a man or woman. Twenty-six female patients $(83.87 \%)$ preferred receiving the bath with female professionals and five $(16.13 \%)$ did not mind whether a man or a woman gave them the bath. Among the male patients, $31(77.5 \%)$ reported they did not mind what the professional's gender was, seven (17.5\%) preferred that male professionals give them the bath and two (5\%) preferred female professionals.

Statistically significant differences were found in the three evaluations $(p<0.0001)$ concerning anxiety generated in bed and shower baths analyzed through the repeated measures ANOVA as shown in Figure 1. The study revealed that patients with AMI presented levels of anxiety significantly higher in the bed bath than in the shower bath, especially before the bed bath as shown in Figure 1.

State-anxiety

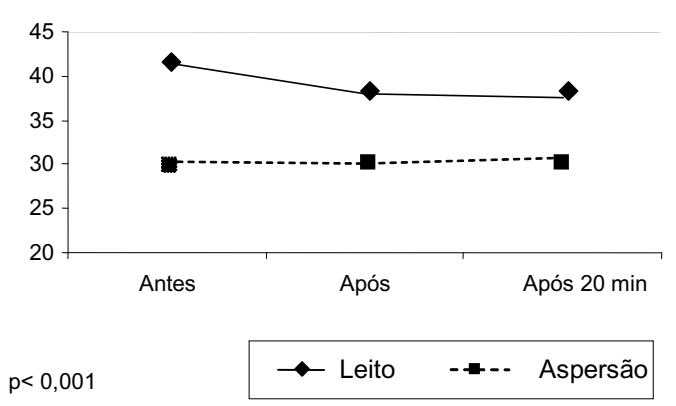

Figure 1 - State-anxiety according to the type of bath at the three points of evaluation. São Paulo, SP, Brazil 2007

We verified that there were not variations in patients' vital parameters (cardiac frequency, respiratory frequency and systolic and diastolic blood pressures) measured at the three previously described points and which could be related to the state of anxiety of patients as shown in Table 1.

Table 1 - Results obtained through Generalized Estimating Equations for state-anxiety according to systolic blood pressure, diastolic blood pressure, respiratory frequency and cardiac frequency in the types of bath and evaluations. São Paulo, SP, Brazil 2007

\begin{tabular}{lll}
\hline \multicolumn{1}{c}{ Variable } & \multicolumn{1}{c}{ Parameters } & p-value \\
\hline Systolic blood pressure & \multicolumn{1}{c}{ bed vs. shower } & 0.4302 \\
& before vs. after & 0.0542 \\
& after 20 min vs. before & 0.3546 \\
& After vs. after 20 min & 0.2968 \\
Diastolic blood pressure & & \\
& bed vs. shower & 0.7108 \\
& after vs. before & 0.5543 \\
& after 20 min vs. before & 0.1577 \\
& After vs. after 20 min & 0.3759
\end{tabular}


Table 1 - Continuation

\begin{tabular}{lll}
\hline \multicolumn{1}{c}{ Variable } & \multicolumn{1}{c}{ Parameters } & p-value \\
\hline Respiratory frequency & & \\
& bed vs. shower & 0.8585 \\
& after vs. before & 0.1237 \\
& after 20 min vs. before & 0.0674 \\
& After vs. after 20 min & 0.6539 \\
Cardiac frequency & & \\
& bed vs. shower & 0.4734 \\
& after vs. before & 0.7454 \\
& after 20 min vs. before & 0.1427 \\
& After vs. after 20 min & 0.0516 \\
\hline
\end{tabular}

The only antecedent variable that interfered in patients' anxiety was hypertension, revealing that hypertensive patients presented a higher level of anxiety due to baths (shower and bed) than non-hypertensive patients, as shown in Figure 2.

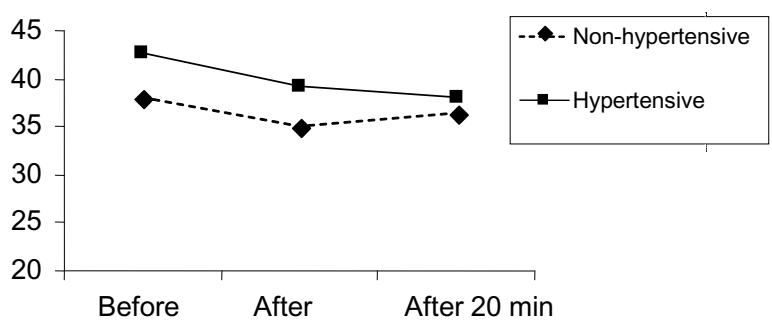

Figure 2 - Patients' anxiety according to hypertension during the bed baths. São Paulo, SP, Brazil 2007

No other antecedent variable interfered in patients' anxiety due to the baths, as shown in Tables 2 and 3.

Table 2 - Results of the repetitive measures ANOVA for the state-anxiety according to gender, age, previous hospitalization and bed bath, preferences, benzodiazepines and risk factors. São Paulo, SP, Brazil 2007

\begin{tabular}{|c|c|c|c|}
\hline Variable & Factor & $\mathbf{F}$ & p-value \\
\hline \multirow{12}{*}{ state-anxiety } & Bath vs. evaluations vs. gender & 0.39 & 0.6774 \\
\hline & Bath vs. evaluations vs. age & 0.30 & 0.7432 \\
\hline & Bath vs. evaluations vs. previous bed bath & 0.30 & 0.7442 \\
\hline & Bath vs. evaluations vs. previous hospitalization & 0.82 & 0.4425 \\
\hline & Bath vs. evaluations vs. preferences & 0.21 & 0.8115 \\
\hline & Bath vs. evaluations vs. anxiolytics & 0.08 & 0.9218 \\
\hline & Bath vs. evaluation vs. Diabetes Mellitus (DM) & 0.36 & 0.6988 \\
\hline & Bath vs. evaluations vs. dyslipidemia & 0.95 & 0.3888 \\
\hline & Bath vs. evaluations vs. obesity & 0.46 & 0.6347 \\
\hline & Bath vs. evaluations vs. family history & 0.64 & 0.5313 \\
\hline & Bath vs. evaluations vs. smoking & 0 & 0.9985 \\
\hline & Bath vs. evaluations vs. sedentariness & 1.18 & 0.3092 \\
\hline
\end{tabular}

Table 3 - Results of Person's correlation between stateanxiety of bed bath and shower bath and trait-anxiety. São Paulo, SP, Brazil 2007

\begin{tabular}{rlccc}
\hline Variable & Bath & N & rs & p-value(*) \\
\hline \multirow{2}{*}{ state-anxiety } & Bed & 71 & -0.0344 & 0.7756 \\
& Shower & 71 & 0.1165 & 0.3335 \\
\hline
\end{tabular}

\section{Discussion}

The data obtained in relation to anxiety indicate two main results. The first is that anxiety generated from a bed bath is higher than that generated from a shower bath in the three evaluations. This fact might have occurred because patients perceived the bed bath as a threat to their safety due to invasion of privacy and intimacy, which increased their level of anxiety(8). These manifestations are due to the cultural universe in which being socially appropriate implies wearing clothes; one should not expose his/her body in the presence of another and nudity is related to sensuality and sexuality ${ }^{(13,21)}$

The second main result is that anxiety generated by patients' expectation of receiving a bed bath was higher than anxiety generated during the bath itself. This same result was found in another study in which anxiety was higher before a bed bath (score $43.98 \%$ ) diminishing right after the procedure (score $=37.89)^{(22)}$.

The act of "awaiting" some event causes diverse expectations, feelings and emotions(7). During hospitalization, especially in intensive care units, there are several stressors and situations that alter life habits, generating expectations in patients that might make the waiting period distressing and lead to stress and anxiety $^{(23)}$.

Health professionals have traditionally considered 
increased levels of anxiety to be detectable through changes in cardiac frequency and blood pressure. The verbalization of anxiety, agitation and increased blood pressure and cardiac frequency are the most important indicators of anxiety ${ }^{(24)}$. However, these parameters were not influenced by anxiety during bed or shower baths, even in moderate levels. Nonetheless, it is worth noting that the evaluated patients were using medications such as anti-hypertensive medications and betablockers, which might have interfered in the results.

In regard to the antecedent variables, we observed that the only variable that influenced the anxiety of patients was hypertension, showing that hypertensive patients presented higher levels of anxiety than nonhypertensive patients in bed and shower baths. Similar results were obtained in another study ${ }^{(25)}$, in which the levels of state and trait anxiety of hypertensive patients were significantly higher than the population in general.

There is no consensus in the literature concerning the relation of other antecedent variables and patients' anxiety. Among these variables, a somewhat surprising result was the fact that anxiety did not alter in situations in which patients' preferences regarding the gender of the professionals were unsatisfied.

Nurses are recommended, due to their academic training, to take into account not only the patients' conditions and level of dependency but also their preferences. Patients should be allowed to participate in the planning and delivery of care related to their lives and health whenever possible(26).

The results obtained in this study revealed that anxiety did not increase when patients' preferences were contradicted. This contributes to the profession since there is a predominance of female professionals in nursing and male professionals are not always available to satisfy the patients' preferences.

In view of the presented contexts concerning the anxiety generated in the baths and considering the individual differences of each patient, it is the nurses' role to pay more attention in the planning and realization of such procedures. From this perspective, we believe that professionals should be encouraged to provide clear and objective orientation in their nursing activities related to bed baths, seeking to clarify the factors that trigger stress and anxiety.

\section{Conclusion}

The level of anxiety during bed baths is significantly higher than that generated during shower baths. Therefore, factors that influence it should be modified through strategies in order to provide information to patients in relation to this procedure.

Despite the bath's relevance and the fact it is the most performed nursing activity, it has been little explored. Studies comparing levels of anxiety during several nursing procedures are extremely important for the daily practice of nursing care. Professionals should be concerned not only with the patients' physiological aspect but also with their psychological aspect, seeking emotional balance concomitantly with seeking the physical recovery of patients.

\section{References}

1. Moser DK, Dracup K. Is anxiety early after myocardial infarction associated with subsequent ischemic and arrhythmic events? Psychosom Med 1996; 58(5):395-401.

2. An K, De Jong MJ, Riegel BJ, McKinley S, Garvin BJ, Doering $\mathrm{LV}$, et al. A cross-sectional examination of changes in anxiety early after acute myocardial infarction. Heart Lung 2004; 33(2):75-82.

3. Lane D, Carroll D, Ring C, Beevers DG, Lip GY. Effects of depression and anxiety on mortality and quality-of-life 4 months after myocardial infarction. J Psychosom Res 2000; 49(4):229-38.

4. Frazier SK, Moser DK, Riegel B, McKinley S, Blakely W, Kim $K A$, et al. Critical care nurses' assessment of patients' anxiety: reliance on physiological and behavioral parameters. Am J Crit Care 2002; 11(1):57-64.

5. Okano Y, Utsunomiya T, Yano K. Effect of mental stress on hemodynamics and left ventricular diastolic function in patients with ischemic heart disease. Jpn Circ J 1998; 62(3):173-7.

6. Novaes MAFP, Romano BW, Lage SG. Internação em UTI.
Variáveis que interferem na resposta emocional. Arq Bras Cardiol 1996; 67(2):99-102.

7. Grazziano ES, Bianchi ERF. Nível de ansiedade de clientes submetidos a cineangiografia e de seus acompanhantes. Rev Latino-am Enfermagem 2004; 12(2):168-74.

8. Carvalho DV. Intrusão física e visual no espaço pessoal dos pacientes hospitalizados acamados [dissertação]. São Paulo (SP): Universidade de São Paulo. Escola de Enfermagem da USP; 1977.

9. Pupulim JSL, Sawada NO. Exposição corporal do cliente no atendimento das necessidades básicas em UTI: incidentes críticos relatados por enfermeiras / Physical exposure of clients in care for basic needs at an ICU: critical incidents reported by nurses. Rev Latino-am Enfermagem 2005; 13(3):388-96.

10. Lopes CLR, Barbosa MA, Teixeira MEM, Aquino RVP. Percepção dos pacientes, sem capacidade para autocuidar-se, sobre a operacionalização do banho no leito. Rev Bras Enferm 1996; 49(2):259-66.

11. Ogasawara M. Banho no leito: uma contribuição ao enfermeiro 
baseada na percepção do paciente/ cliente [dissertação]. Rio de Janeiro (RJ): Escola de Enfermagem Anna Nery / UFRJ; 1989.

12. Carvalho AMS. Cuidados de enfermagem ao corpo nu: mulher, repressão sexual e vergonha. [dissertação]. São Paulo (SP): Instituto de Psicologia / USP; 2005.

13. Pupulim JSL, Sawada NO. O cuidado de enfermagem e a invasão da privacidade do doente: uma questão ético-moral. Rev Latino-am Enfermagem. 2002; 10(3):433-8.

14. Davim RMB, Torres GV, Silva RAR, Silva DAR. Percepção de pacientes acamados quanto ao banho no leito: um estudo de caso. Rev Tec-Cient Enferm. 2004; 2(7):24-6.

15. Ide CAC. O paciente de UTI e a percepção dos cuidados de higiene corporal [dissertação]. São Paulo (SP): Escola de Enfermagem / USP; 1984.

16. Figueredo NMA, Machado WCA. A nudez do cliente: o (des) equilíbrio no cuidado de enfermagem. Rev Enferm UERJ. 1996;4(2):143-52.

17. Amatuzzi MLL, Barreto MCC, Litvoc J, Leme LEG. Linguagem metodológica: Parte 1. Acta Ortop Bras 2006; 14(1):53-6.

18. Ignácio DS. Ansiedade e angioplastia coronária transluminal percutânea (ACTP): uma contribuição para a enfermagem. [dissertação]. São Paulo (SP): Escola de Enfermagem/USP; 2004.

19. Gatti MF. A música como intervenção redutora da ansiedade do profissional de serviço de emergência: utopia ou realidade? [dissertação]. São Paulo (SP): Escola de Enfermagem/USP; 2005.

20. Grey M. Desenhos experimentais e quase-experimentais In: Lobiondo-Wood G, Haber J. Pesquisa em enfermagem: métodos, avaliação crítica e utilização. $4^{a}$ ed. Rio de Janeiro (RJ): Guanabara Koogan; 2001.

21. Silveira MFA. Estar despido na unidade de terapia intensiva: duas percepções, um encontro. Rev Enferm UERJ. 1997; 5(2):449-59.

22. Barsevick A, Llewellyn J. A comparison of the anxietyreducing potential of two techniques of bathing. Nurs Res 1982 31(1):22-7.

23. Romano BW. A família e o adoecer durante a hospitalização. Rev Soc Cardiol Estado São Paulo. 1997; 7(5 Supl A):58-62. 24. Frazier SK, Moser DK, O'Brien JL, Garvin BJ, An K, Macko M. Management of anxiety after acute myocardial infarction. Heart Lung 2002; 31(6):411-20.

25. Stela F. Avaliação de traços e estados de ansiedade em pacientes hipertensos de centro de saúde. J Bras Psiquiatr 1991; 40(10):497-9.

26. Mendes VLPS. Gerenciando qualidade em serviços de saúde. Rev Bras Enferm 1993; 46(3/4):211-25. 